\title{
Aerobic Exercise and Whole-Body Vibration in Offsetting Bone Loss in Older Adults
}

\author{
Pei-Yang Liu, ${ }^{1}$ Kenneth Brummel-Smith, ${ }^{2}$ and Jasminka Z. Ilich ${ }^{1}$ \\ ${ }^{1}$ Department of Nutrition, Food and Exercise Sciences, The Florida State University, 120 Convocation Way, \\ 418 Sandels Building, Tallahassee, FL 32306-1493, USA \\ ${ }^{2}$ College of Medicine, The Florida State University, Tallahassee, FL 32306-4300, USA \\ Correspondence should be addressed to Jasminka Z. Ilich, jilichernst@fsu.edu
}

Received 24 August 2010; Accepted 2 December 2010

Academic Editor: Ben Hurley

Copyright () 2011 Pei-Yang Liu et al. This is an open access article distributed under the Creative Commons Attribution License, which permits unrestricted use, distribution, and reproduction in any medium, provided the original work is properly cited.

\begin{abstract}
Osteoporosis and its associated fractures are common complications of aging and most strategies to prevent and/or treat bone loss focused on antiresorptive medications. However, aerobic exercise (AEX) and/or whole-body vibration (WBV) might have beneficial effect on bone mass and provide an alternative approach to increase or maintain bone mineral density (BMD) and reduce the risk of fractures. The purpose of this paper was to investigate the potential benefits of AEX and WBV on BMD in older population and discuss the possible mechanisms of action. Several online databases were utilized and based on the available literature the consensus is that both AEX and WBV may increase spine and femoral BMD in older adults. Therefore, AEX and WBV could serve as nonpharmacological and complementary approaches to increasing/maintaining BMD. However, it is uncertain if noted effects could be permanent and further studies are needed to investigate sustainability of either type of the exercise.
\end{abstract}

\section{Introduction}

Osteoporosis, a disorder characterized by the progressive loss of bone tissue and microarchitectural deterioration, remains a public health problem and reduces the quality of life for the aging population [1]. It has been estimated that with increasing age, bone mineral density (BMD) in women decreases $1-2 \%$ per year at the femoral neck and spine (excluding the influence of corticosteroid use) [2]. To date, the predominant medical strategies to prevent and/or treat postmenopausal bone loss have focused on antiresorptive medications (i.e., bisphosphonates). However, these treatments might be limited due to adverse side effects, questionable compliance, and long-term safety concerns [3]. Simple aerobic exercises (AEX) like walking, jogging, and running could provide an important role in maintaining and/or increasing bone density in women [4]. Therefore, implementing nonpharmacological treatments that have little or no inherent side effects (like exercise), either alone or in combination with pharmaceutical agents, is critical.

Although regular AEX may improve bone status and/or maintain bone mass preventing fractures [5], relatively vigorous aerobic, weight-bearing, or strength training regimens are even more effective [6]. However, in some cases vigorous exercise may increase the risk of injury, particularly in the elderly. Also, compliance to vigorous exercise is likely to be low in the older population. The published studies examining the positive role for AEX in relation to bone mineral density (BMD) are inconclusive. Several controlled intervention studies have shown positive effects on BMD [7], while others have yielded either mixed [8] or negative results [9]. These differences could be attributed to different study populations (young or old adults), the level of intensity tested (low or high), and/or kind of activities (running, jogging, etc.) employed. To narrow down the discussing realm for this review, we focus on the impact of organized aerobic activities performed on treadmill and other gym equipment, as well as running and/or walking, on BMD in older adults.

Whole-body vibration (WBV) or vibration training is a relatively new type of exercise in the "Wellness" industry. Previously used for astronauts, WBV has been reported to have the positive effect on BMD, similar to that of AEX in both animal $[10,11]$ and human $[12,13]$ studies. Some studies also compared the effect of WBV and resistance 
training on muscle strength with positive results $[14,15]$. Current WBV machines deliver vibrations at a frequency between 15 and $60 \mathrm{~Hz}$. The resonance frequencies of the spine occur between 5 and $15 \mathrm{~Hz}$ [16] which are also the frequencies considered to be a causative factor in low back pain [17] and circulatory disorders like Raynaud's phenomenon [18]. However, WBV-related injuries (back pain, muscular discomfort, etc.) can be prevented by limiting the duration to a maximum of 10 minutes and maintaining the posture of the participant in a semisquat stance which involves the leg muscles reducing the transmission of vibrations to the head [19]. Therefore, WBV may be safer to apply and easier to comply with than AEX, particularly in a community setting. However, there is no consensus regarding the benefits, safety, and long-term application of WBV. To our knowledge, there is also no comparison of the effects of WBV and AEX on $\mathrm{BMD}$ in elderly. Therefore, the purpose of this paper was to evaluate and compare the effect of AEX and WBV on BMD at various skeletal sites in older population and to explain the possible mechanisms of their action on bone.

\section{Methods}

Papers on AEX and whole-body vibration published in English were searched using PubMed and MedLine (FirstSearch) databases. Combinations of the following phrases as keywords were used in the search "Aerobic exercise/ whole-body vibration," "bone mineral density/content," "older women/female," "older men/male," and "running/ walking/jumping" and would have to be present in the title, abstract, or keywords. AEX included treadmill walking, stepping exercise, and jumping. Studies with strength and resistance exercise were not included in this context. After excluding studies with vitamin D and calcium supplementation, or those involving subjects on medications and different chronic conditions, 17 studies were selected and are discussed in this paper for the effects of AEX. After excluding studies that examined WBV but focused on bone implants and those in which medications and other special treatment were used, 4 studies were selected and discussed in this paper. A snapshot of the relevant studies and their overall description is shown in Tables 1 and 2.

\section{Effect of Aerobic Exercise on Bone in Older Population}

3.1. Organized Aerobic Activities. Women entering menopause face many challenges regarding their bone health, especially those with a history of or current inactivity [37]. Therefore, engaging the elderly in exercise programs is necessary to maintain $\mathrm{BMD}$ and increase the quality of life. Most of resistance exercises have shown a positive effect on increasing or maintaining BMD in postmenopausal women [38, 39]. Whether AEX has the same effect is questionable. Results from a meta-analysis revealed that AEX maintained spine and significantly increased femoral neck BMD, suggesting that the femoral neck might be more responsive to high-impact AEX than the lumbar spine
[40]. Welsh and Rutherford [33] found that 1-year AEX including high-load step and jumping significantly increased femoral neck and trochanter BMD in a group of previously sedentary men and postmenopausal women. In addition, Chien et al. [21] found that a 6-month AEX intervention, including graded treadmill-walking and stepping, significantly increased femoral neck, but not spine BMD in Chinese postmenopausal women. Even in the chronic stroke population, AEX maintained the femoral neck BMD, while a significant reduction in BMD was observed in controls [32]. These results suggest that AEX has positive impact on femoral neck BMD.

Confounding results still exist as some studies have shown that AEX did not enhance BMD in postmenopausal women [28, 30, 41]. These conflicting results were most likely due to insufficient intensity and frequency of exercise, small sample sizes, and the choice of measurement site employed in each study. The most frequently used duration and frequency of AEX were 30-60 minutes per session, 23 times a week. In a community exercise program, it was found that 1 year of AEX combined with strength training did not show an improvement in BMD at several skeletal sites in women aged 60 years and over [28]. Martin and Notelovitz [30] showed that 1 year of moderate AEX did not improve spine or forearm BMD due to inadequate sample sizes to detect small changes in bone. Other limitations were the low intensity of exercise and the lack of the involvement of upper extremities activities. Results from the meta-analysis showed that exercise did not improve femoral neck BMD in postmenopausal women [41] thought resistance training was included in their data analysis. The conflicting conclusion may be due to the combination of aerobic and resistance exercise in their data analysis and the different choice of measurement such as forearm or spine. If we only consider the effect of AEX on BMD, not including other kinds of exercises, AEX seems to increase femoral BMD in older adults.

3.2. Running and Walking. Some longitudinal studies examined the impact of running on BMD in older individuals. Although Wiswell et al. [34] found that 54 male runners aged 40 to 80 years maintained their hip and spine BMD over a 4- to 5-year running period by self-reporting training hours compared to their baseline measurements, the age range used may be too large to draw meaningful conclusions. A similar study revealed that runners exhibited a lower age-related bone loss compared to controls although both runners and controls had a significant decrease in spine BMD after a 5year followup [31]. A 9-year longitudinal study following the running subjects showed that those who maintained their training volume lost less bone in the spine than those who did not maintain their running regimens [29]. These results demonstrate that running is beneficial to maintain the BMD for elderly. In contrast, Kirk et al. [26] found that postmenopausal runners tended to have lower spine BMD than age- and height-matched controls, indicating that running prevents hip BMD loss, but it may not maintain agerelated reduction of spine BMD in older men and women. 
TABLE 1: Snap-shot of the relevant studies* investigating the relationship of aerobic exercise and BMD of various skeletal sites.

\begin{tabular}{|c|c|c|c|}
\hline Authors (reference) & Design/subjects & $\begin{array}{l}\text { Bone measurements } \\
(\mathrm{BMD} / \mathrm{BMC})\end{array}$ & Results \\
\hline $\begin{array}{l}\text { Brook-Wavell et al. } \\
1997[20]\end{array}$ & $\begin{array}{l}78 \text { sedentary women were assigned to } \\
\text { either brisk walking }(n=38) \text { for } 1 \text { year } \\
\text { or controls }(n=40)\end{array}$ & $\begin{array}{l}\text { DXA (Lunar DPX-L) (GE } \\
\text { Medical Systems, } \\
\text { Madison, WI) and McCue } \\
\text { Ultrasonics (Winchester, } \\
\text { UK) }\end{array}$ & $\begin{array}{l}\text { Regular brisk walking for } 1 \text { year } \\
\text { increased BMD significantly at calcaneus } \\
\text { and almost significantly at the lumbar } \\
\text { spine in postmenopausal women } \\
\text { compared to controls }\end{array}$ \\
\hline Chien et al. 2000 [21] & $\begin{array}{l}43 \text { postmenopausal Chinese women were } \\
\text { assigned to either treadmill walking or } \\
\text { stepping exercise }(n=23) \text { for } 6 \text {-month } \\
\text { and nonexercise controls }(n=21) \text { for } 2 \\
\text { years }\end{array}$ & $\begin{array}{l}\text { DXA (XR-26 Mark II } \\
\text { machine, Norland Corp., } \\
\text { WI) }\end{array}$ & $\begin{array}{l}\text { Femoral neck BMD was significantly } \\
\text { increased in postmenopausal women on } \\
\text { treadmill compared to controls }\end{array}$ \\
\hline $\begin{array}{l}\text { Ebrahim et al. } 1997 \\
\text { [22] }\end{array}$ & $\begin{array}{l}98 \text { postmenopausal women were } \\
\text { randomly allocated to brisk walking } \\
(n=49) \text { or placebo group }(n=48)\end{array}$ & $\begin{array}{l}\text { DXA (Lunar DPX) (GE } \\
\text { Medical Systems, } \\
\text { Madison, WI) }\end{array}$ & $\begin{array}{l}\text { Brisk walking for } 2 \text { years had less femoral } \\
\text { neck BMD loss than placebo groups }\end{array}$ \\
\hline Hatori et al. 1993 [8] & $\begin{array}{l}33 \text { postmenopausal women were } \\
\text { randomly assigned to } 12 \text { controls } \\
(n=12) \text {, moderate intensity walking } \\
(n=9) \text {, and high-intensity walking } \\
\text { group }(n=12) \text { for } 7 \text { months }\end{array}$ & $\begin{array}{l}\text { DXA (QDR-1000) } \\
\text { (Hologic Inc., Bedford, } \\
\text { MA) }\end{array}$ & $\begin{array}{l}\text { 7-month high-intensity walking } \\
\text { attenuated bone loss at the lumbar spine } \\
\text { in postmenopausal women }\end{array}$ \\
\hline $\begin{array}{l}\text { Ilich-Ernst et al. } 2002 \\
\text { [23] }\end{array}$ & $\begin{array}{l}77 \text { older Caucasian women were assessed } \\
\text { for past physical activity and past and } \\
\text { present walking }\end{array}$ & $\begin{array}{l}\text { DXA (Lunar DPX-MD) } \\
\text { (GE Medical Systems, } \\
\text { Madison, WI) }\end{array}$ & $\begin{array}{l}\text { Hip bone mass increased in subjects } \\
\text { walking at a brisk or fast pace }\end{array}$ \\
\hline $\begin{array}{l}\text { Ilich and Brownbill } \\
2008[24]\end{array}$ & $\begin{array}{l}97 \text { postmenopausal women were } \\
\text { compared regarding the walking pace } \\
\text { (slow, fast, or brisk) }\end{array}$ & $\begin{array}{l}\text { DXA (Lunar DPX-MD) } \\
\text { (GE Medical Systems, } \\
\text { Madison, WI) }\end{array}$ & $\begin{array}{l}\text { A significantly higher femoral neck } \\
\text { BMD/BMC at a brisk walking pace than } \\
\text { a slow walking pace }\end{array}$ \\
\hline $\begin{array}{l}\text { Iwamoto et al. } 2002 \\
\text { [25] }\end{array}$ & $\begin{array}{l}35 \text { postmenopausal women were } \\
\text { assigned to either brisk walking and } \\
\text { gymnastic training }(n=15) \text { or controls } \\
(n=20) \text { for } 1 \text { years }\end{array}$ & $\begin{array}{l}\text { DXA (XR-26 or XR-36) } \\
\text { (Norland, Fort Atkinson, } \\
\text { WI) }\end{array}$ & $\begin{array}{l}\text { One year of brisk walking combined with } \\
\text { gymnastic training significantly } \\
\text { increased the spine BMD }\end{array}$ \\
\hline Kirk et al. 1989 [26] & $\begin{array}{l}\text { Premenopausal runners }(n=10) \text { and } \\
\text { postmenopausal women }(n=9) \text { runners } \\
\text { and matched premenopausal sedentary } \\
\text { controls }(n=10) \text { and postmenopausal } \\
\text { sedentary controls }(n=9)\end{array}$ & QCT & $\begin{array}{l}\text { Postmenopausal runners tended to have } \\
\text { lower lumbar spine BMD than } \\
\text { premenopausal women runners and } \\
\text { age-matched controls }\end{array}$ \\
\hline $\begin{array}{l}\text { Krall and } \\
\text { Dawson-Hughes } \\
1994[27]\end{array}$ & $\begin{array}{l}237 \text { healthy Caucasian women were } \\
\text { assessed by questionnaire of current and } \\
\text { historical participation in outdoor } \\
\text { walking }\end{array}$ & $\begin{array}{l}\text { DXA (Lunar DPX) (Lunar } \\
\text { Corp., Madison, WI) }\end{array}$ & $\begin{array}{l}\text { Women who walked more than } \\
7.5 \text { miles/week had higher whole body, } \\
\text { leg, and trunk BMD than those who } \\
\text { walked less than } 1 \text { mile/week }\end{array}$ \\
\hline Lord et al. 1996 [28] & $\begin{array}{l}136 \text { women were assigned to either AEX } \\
\text { with strength training }(n=66) \text { or } \\
\text { control group }(n=70) \text { for } 42 \text { weeks }\end{array}$ & $\begin{array}{l}\text { DXA (Lunar DPX) (Lunar } \\
\text { Corp., Madison, WI) }\end{array}$ & $\begin{array}{l}\text { There was no difference in BMD at } \\
\text { different sites }\end{array}$ \\
\hline Lane et al. 1998 [29] & $\begin{array}{l}\text { Runners }(n=28) \text { and nonrunner } \\
\text { controls }(n=27) \text { were followed for } 9 \\
\text { years }\end{array}$ & QCT & $\begin{array}{l}\text { Runners lost less bone in the spine than } \\
\text { controls }\end{array}$ \\
\hline $\begin{array}{l}\text { Martin and } \\
\text { Notelovitz } 1993 \text { [30] }\end{array}$ & $\begin{array}{l}55 \text { postmenopausal women were } \\
\text { assigned to control }(n=19), 30 \text {-minute } \\
\text { AEX }(n=20) \text {, or } 45 \text {-minute AEX } \\
(n=16) \text { for } 12 \text { months }\end{array}$ & DXA & $\begin{array}{l}\text { Moderate AEX did not improve lumbar } \\
\text { or forearm BMD }\end{array}$ \\
\hline $\begin{array}{l}\text { Michel et al. } 1992 \\
\text { [31] }\end{array}$ & $\begin{array}{l}\text { Elder runners }(n=14) \text { and matched } \\
\text { controls }(n=14) \text { were followed for } 5 \\
\text { years }\end{array}$ & $\begin{array}{l}\text { QCT (Quantitative GE } \\
9800 \text { CT) }\end{array}$ & $\begin{array}{l}\text { Running reduced age-related bone loss } \\
\text { both in women and men over } 50 \text { years of } \\
\text { age }\end{array}$ \\
\hline Pang et al. 2005 [32] & $\begin{array}{l}63 \text { older people with chronic strokes } \\
\text { were randomly assigned to exercise } \\
(n=32) \text { with fitness and mobility } \\
\text { exercise program and control }(n=31) \\
\text { with a seated upper extremity program }\end{array}$ & $\begin{array}{l}\text { DXA (QDR 4500) } \\
\text { (Hologic Inc., Waltham, } \\
\text { MA) }\end{array}$ & $\begin{array}{l}\text { Exercise group maintained the femoral } \\
\text { neck BMD, while a significant reduction } \\
\text { in BMD was observed in controls }\end{array}$ \\
\hline
\end{tabular}


TABle 1: Continued.

\begin{tabular}{llll}
\hline Authors (reference) & Design/subjects & $\begin{array}{l}\text { Bone measurements } \\
\text { (BMD/BMC) }\end{array}$ & Results \\
\hline $\begin{array}{l}\text { Welsh and } \\
\text { Rutherford 1996 [33] }\end{array}$ & $\begin{array}{l}\text { 30 men and women were assigned to } \\
\text { 1-year or nonexercise controls }(n=15)\end{array}$ & $\begin{array}{l}\text { DXA (Lunar DPX-L) } \\
\text { (Lunar Corp., Madison, }\end{array}$ & $\begin{array}{l}\text { WI) } \\
\text { femoral her had significantly increased } \\
\text { while there were no observed changes in } \\
\text { controls }\end{array}$ \\
$\begin{array}{llll}\text { Wiswell et al. 2002 } \\
{[34]}\end{array}$ & $\begin{array}{l}\text { 54-old-male runners were intervened } \\
\text { longitudinally over a 5- to 7-year period }\end{array}$ & $\begin{array}{l}\text { DXA (QDR 1500) } \\
\text { (Hologic, Inc., Bedford, } \\
\text { MA) }\end{array}$ & $\begin{array}{l}\text { Hip and spine BMD were maintained by } \\
\text { a 4- to 5-year running period compared } \\
\text { to their baseline measurement }\end{array}$ \\
\hline
\end{tabular}

DXA = dual energy X-ray absorptiometry, QCT $=$ quantitative computed tomography.

* Reference no. [9] did not show a positive effect on bone and although it is discussed in the text, it is not presented in the table.

TABLE 2: Snap-shot of the relevant studies* investigating the relationship of whole-body vibration and BMD of various skeletal sites.

\begin{tabular}{|c|c|c|c|}
\hline Authors (reference) & Design/subjects & $\begin{array}{l}\text { Bone measurements } \\
(\mathrm{BMD} / \mathrm{BMC})\end{array}$ & Results \\
\hline Gusi et al. 2006 [19] & $\begin{array}{l}28 \text { postmenopausal women were } \\
\text { randomly assigned to either WBV } \\
(12.6 \mathrm{~Hz}, n=14) \text { or walking group (an } \\
\text { hour walking, } n=14 \text { ) for } 8 \text { months }\end{array}$ & $\begin{array}{l}\text { DXA (Norland Inc., Fort } \\
\text { Atkinson, USA) }\end{array}$ & $\begin{array}{l}\text { After } 8 \text { months, femoral neck BMD in } \\
\text { the WBV group was increased by } 4.3 \% \\
\text { compared to the walking group. There } \\
\text { were no observed change at the lumbar } \\
\text { spine and other sites of the hip between } \\
\text { two groups }\end{array}$ \\
\hline $\begin{array}{l}\text { Rubin et al. } 2004 \\
\text { [13] }\end{array}$ & $\begin{array}{l}24 \text { postmenopausal women were } \\
\text { randomly assigned to either WBV } \\
(30 \mathrm{~Hz}, n=12) \text { or placebo vibration } \\
\text { devices }(n=12) \text { for two } 10 \text { minutes per } \\
\text { day for } 6 \text { months }\end{array}$ & $\begin{array}{l}\text { DXA (QDR 2000) } \\
\text { (Hologic, Waltham, MA, } \\
\text { USA) }\end{array}$ & $\begin{array}{l}\text { There was no difference between WBV } \\
\text { and placebo group. Evaluating people } \\
\text { with highest compliance, placebo lost } \\
2.13 \% \text { of BMD in the femoral neck but } \\
\text { WBV group increased by } 0.04 \%\end{array}$ \\
\hline $\begin{array}{l}\text { Verschueren et al. } \\
2004[35]\end{array}$ & $\begin{array}{l}70 \text { were randomly assigned to WBV } \\
(35-40 \mathrm{~Hz}, n=25) \text {, resistance training } \\
\text { group }(n=22) \text {, or a control group } \\
(n=23) \text { for } 6 \text { months }\end{array}$ & $\begin{array}{l}\text { DXA (QDR-4500A) } \\
\text { (Hologic, Inc., Bedford, } \\
\text { MA) }\end{array}$ & $\begin{array}{l}\text { Total hip BMD in WBV group } \\
\text { significantly increased by } 1.51 \% \\
\text { compared to control group }\end{array}$ \\
\hline
\end{tabular}

DXA = dual energy X-ray absorptiometry.

* Reference no. [36] is discussed in the text, but it is not presented in the table as it is a one-subject study.

While these results did not demonstrate positive effect on spine, they are consistent with the mechanostat theory that the BMD of a lower limb, a primary weight-bearing site, benefits the most from running [42].

Ideally, running and walking could be an effective measure to prevent the loss of bone mass for the older population; however, compliance with moderate to intensive exercise is questionable. Low-intensity AEX such as walking has a lower impact force upon the skeleton compared to running; therefore, it might offer an inferior osteogenic stimulus. Walking as a physical activity may be beneficial for postmenopausal women as well as elderly population, but it may depend on walking speed, with brisk and fast pace being more advantageous [27]. Krall and Dawson-Hughes [27] examined the impact of current and past walking on BMD in 237 healthy Caucasian women (43-72 years) and found that women who walked more than 7.5 miles/week had higher whole body, leg, and trunk BMD compared to those who walked less than 1 mile/week. Furthermore, the number of miles walked per week during a 1-year period was positively correlated with the rate of BMD increase in the lower limbs. A recent meta-analysis reported that walking had favorable effects on hip, but not spine [43]. However, an earlier meta-analysis results showed that walking had a positive significant effect on spine but not on femoral BMD [44]. This contradiction is probably due to including the same groups of population twice in their analysis and the combination of other exercise modes with walking.

Based on the observational and intervention studies investigating the influence of different walking regimens on BMD [20, 23, 24], it was suggested that brisk and fast walking pace is more beneficial in specific skeletal sites, for example, foot and calcaneal bones [20]. Ilich-Ernst et al. [23] evaluated the effect of self-reported past and current walking routines (including normal, fast, and brisk pace) on BMD in older Caucasian women and found that both forearm and hip BMD were higher in the subjects that were able to walk at a brisk or fast pace. Similarly, in a 3-year evaluation of the effects of walking and other habitual physical activities (not necessarily aerobic) on BMD in postmenopausal women, Ilich and Brownbill [24] reported that walking at a faster pace, involvement in sports/recreational activities, and even participation in low-impact physical activities were essential in augmenting bone mass. In a randomized study, it was shown that one year of brisk walking significantly increased calcaneal BMD and slightly increased spine BMD, although not significantly [20]. Similarly, a 2-year brisk walking regimen significantly reduced loss of BMD at femoral neck, 
but there was no difference at the spine BMD [22]. These results support walking as an effective method of increasing BMD and confirm that a brisk and fast walking pace may, in addition to femoral BMD, also benefit calcaneus and forearm BMD. However, most of the studies have been done in women while older men have been less investigated regarding the osteogenic response to walking and running.

There is a consensus that a combination of aerobic and anaerobic exercise is more effective in improving bone mass than either one alone [45]. One year of brisk walking combined with gymnastic training either increased or maintained the spine BMD in postmenopausal women [25]. Results from an earlier meta-analysis showed that walking with other AEXs significantly affected the BMD at spine, but not hip [46]. Bone mass increases or decreases in response to mechanical loading depending on whether the thresholds controlling bone formation and resorption have been reached [47]. A few studies have demonstrated the importance of walking intensity on BMD preservation in postmenopausal women. Hatori et al. [8] reported that 7 months of walking with an intensity above $110 \%$ of the heart rate at its anaerobic threshold attenuated bone loss in the spine of postmenopausal women, whereas walking at an intensity below $90 \%$ of the heart rate at its anaerobic threshold had no influence on BMD. Similarly, Borer et al. [48] confirmed that fast walking pace increased leg and total BMD in early postmenopausal women who were engaged in 15 weeks of walking. These studies demonstrate positive effect of walking intensity on BMD at different skeletal sites. The greater response to the higher intensity walking may be due to the elevated ground reaction forces that occur at a faster walking pace. A failure to show increase in spine BMD during a walking study by Cavanaugh and Cann [9] in 55-year-old postmenopausal women may be due to the employment of lower walking intensities. Therefore, a combination of different kinds of AEXs may be the most efficient approach to reach desired exercise intensity to enhance or maintain bone mass at different skeletal sites in postmenopausal women.

\section{Possible Mechanism by Which Aerobic Exercise Affects Bone}

It is generally accepted that mechanical loading on bones is probably one of the ways to induce skeleton's structural changes and increase bone mass. Physical activity induces a mechanical load on bone tissues due to external forces and muscle contractions, the latter exerting the greater force on bones than any other weight-associated gravitational forces. To withstand the rigor of various functional activities, bone tissue rapidly accommodates changes in its microenvironment [49]. Although the mechanism of mechanical loading effects on bone is not completely understood, it is postulated that it is due to the mechanotransduction of a load. This mechanotransduction is carried out through fluid flow near and between osteocytes (mature cells within the mineralized bone matrix) [50]. In vivo and in vitro studies indicate that mechanical stimuli increase strain, loading frequency, and fluid flow, all of which have an osteogenic effect [51]. However, several conditions must be met to affect bone positively: (1) the strain produced by loading must be of high enough magnitude to exceed the minimum effective strain (or threshold) [52]; (2) the strain should be applied in an intermittent fashion [51]; (3) loading should produce a "different from normal" strain distribution within the bone [51]. In addition, recent research implies that frequent loading on bone without rest may not allow sufficient time for osteocyte fluid flow to recover from inertial dumping between each load cycle. Therefore, fluid flow and subsequent osteocyte stimulation might be reduced or completely inhibited after the first loading cycle. If so, inserting short time periods between loadings will allow for recovery from the inertial dumping effect and facilitate osteocyte stimulation. This effect was recently shown in vivo, in both young and older animals and in two different species (avian and murine); by inserting $10 \mathrm{sec}$, rest period between each loading cycle greatly enhanced the osteogenic potential of the low-magnitude regimen [53].

While much emphasis is given to the resident bone cells (primarily osteocytes) and their response to the local load imposed on bone, new research implies that response to the mechanical load (exercise) may also be neuronally regulated and therefore systemic, with a resultant effect on multiple bones [54]. Sample et al. [54] showed that in young rats, intense mechanical stimulation of one limb can illicit a response in other limbs and even in the entire skeleton. This newest discovery may explain why increased BMD after localized mechanical stimulation could be recorded in skeletal sites that were not directly stimulated (e.g., increased forearm BMD with walking) [23].

\section{The Effect of Whole-Body Vibration on Bone}

WBV is a new approach that is currently being tested for its effect on BMD and bone strength $[51,55]$. There are two main types of vibration devices/techniques: (a) upand-down oscillating vibration plates and (b) reciprocating vertical displacements on the left and right sides of a fulcrum, providing the lateral oscillations. Rubin et al. [11, 51] observed an increase in bone formation in weight-bearing sites and a substantial increase in the quality and quantity of trabecular bone in sheep exposed to a low-intensity, highfrequency $(20-50 \mathrm{~Hz})$ mechanical stimuli [11]. It is well established that decreased estrogen due to ovariectomy in animal models decreases the bone formation rate resulting in a decrease in bone mass. In rats, Flieger et al. [56] found that low-level, high-frequency mechanical loading $(50 \mathrm{~Hz})$ was effective in preventing bone loss shortly after ovariectomy. Even in aging mice, low- and high-intensity WBV significantly increased mineralized bone surfaces [57]. This suggests that WBV may be a suitable bone-sparing therapy.

Bone is known to adapt to different loading conditions and the loading-induced strains are believed to be based on the adaptation of the bone tissue. For that reason, researchers usually administered frequencies at $15-35 \mathrm{~Hz}$ to obtain the maximum transmissibility of the mechanical loading 
produced by the vibrating plate. While the adaptation to the mechanical loading is most likely the limiting factor, elderly subjects have been shown to benefit from simulated mechanical loading. Early-postmenopausal women who stood on a vertical plate of low magnitude $(0.3 \mathrm{~g})$ and high frequency $(30 \mathrm{~Hz})$, twice/day (10 minutes each) for a year, showed no difference in BMD compared with controls [13]. However, evaluating those with $\geq 80 \%$ compliance, controls lost $2.13 \%$ of bone mass in the femoral neck, whereas treatment group gained $0.04 \%$ over one year. When the analysis focused on the lower weight ( $<65 \mathrm{~kg}$ women, a known risk factor for osteoporosis) and those who were compliant, the benefit of treatment became significant and demonstrated a 3\% and $>2 \%$ positive difference at the spine and femoral neck BMD, respectively.

Any potential benefit of WBV strongly depends on compliance and vibration stimulus that can be varied in multiple ways (including type, magnitude, frequency, and duration), and different types of vibration loading are likely to result in different effects on BMD [58]. Low-level mechanical stimuli may be more effective in lighter than in heavier women, particularly for hip BMD. A recent meta-analysis (although published only as an abstract) also showed that low-intensity WBV effectively attenuated postmenopausal BMD decline in hip but not in spine [59]. Another study in postmenopausal women where intervention was employed on a vertical plate, higher magnitude (2.28-5.09 g), and high-frequency (35$40 \mathrm{~Hz}$ ) for 6 months showed a significant $1.51 \%$ net increase in total hip BMD but not in total body or spine BMD [35]. A 5-month study examining an older man (79 years) employing multiple vibration intensities and frequencies to evaluate BMD showed detectable increase in spine, femoral neck, trochanter, and forearm BMD [36]. Though this study demonstrated positive results on BMD, only one participant was examined, therefore, the results cannot be representative of the larger group.

Gusi et al. [19] investigated whether WBV is more effective than walking for maintaining or increasing BMD. They compared the effect of walking and WBV using a reciprocating plate, low amplitude $(3 \mathrm{~mm})$, and medium frequency $(12.6 \mathrm{~Hz})$, for 8 months on BMD in postmenopausal women. After 8 months, femoral neck BMD was significantly $(4.3 \%)$ higher in the WBV group than in the walking group. The difference in BMD at spine and other sites of the hip was not significant between two groups. The results suggest that the vibration could be an easier approach to increase BMD at the femoral neck than walking and could be applied to provide a surrogate for suppressed bone loss of hip after menopause. However, at the present time, it is too early to make a conclusion due to insufficient research in elderly adults and varied vibration protocols. Compliance to WBV in elderly population is another critical concern.

\section{Possible Mechanism by Which Low-Intensity Whole-Body Vibration Affects Bone}

Possible mechanism by which WBV affects bone may be based on the same principle as AEXs that activate the osteoblasts while reducing the activity of the osteoclasts. The strain, magnitude, and frequency are essential factors for the effect of WBV. WBV also increases the sensitivity of musculoskeletal systems to adapt to the mechanical stimulation. Controlled loading study has shown that high-strain magnitude and high-strain rate are the most osteogenic [60]. It has been hypothesized that mechanical stimulation recruits additional osteoblasts and increases the percentage of mineralizing surfaces therefore, increasing the rate of bone formation and decreasing the rate of bone resorption [60].

It has been suggested that the high-frequency vibration may have played an important role in the osteogenic effect. There is a general perception that signals must be large enough to elicit a positive influence on bone mass and morphology. However, the high-frequency stimulation may be capable of influencing skeletal architecture by distributing uniform stresses on bones [61]. Rubin et al. [62, 63] hypothesized that this influence may be achieved directly by mechanical strain, or indirectly through amplification of the signal by intramedullary pressure or fluid flow in bone tissue. The mechanism behind the frequency-dependent adaptive response of bone to stimuli might be the stochastic resonance. Stochastic resonance is a phenomenon in which mechanical noise (broad-band frequency of vibration) enhances the response of a nonlinear system to a weak signal by boosting it over a threshold. The stochastic threshold may be modified through a system such as neuromuscular feedback amplified by the low-level signal [64] or by stimulating skeletal muscle pump activity, resulting in significant effects on circulatory flows and fluid flow through the bone tissue. In addition, previous study has shown that stochastic resonance can enhance mechanosensitivity of different mechanoreceptors in the body, for example, muscle spindles [65]. These findings indicate that vibration stimulation employs multiple ways to influence bone mass and structure.

\section{Conclusions}

In summary, evaluation of the published literature provides evidence of the effectiveness of AEX and WBV in increasing or at least maintaining bone mass in the elderly. The mechanism could be due to increasing the circulation of fluid and activating the osteoblasts while reducing the activity of the osteoclasts via mechanical stimulation. The osteogenic effects of both AEX and WBV could be site specific (to the spine or hip), depending on the exercise load and the type of exercises. The beneficial effects on bone can be maintained for a longer time if the exercise continuesalthough the exercise may not maintain the age-related reduction of BMD in elderly. In addition, the risk of injuries or falls could be high and the compliance to AEX particularly in elderly low. Walking is an inexpensive, practical exercise associated with low injury rates and demonstrates high acceptability by elderly. For these reasons, walking could be an appropriate approach to prevent osteoporosis and maintain bone mass. However, there is evidence that the osteogenic effect of load bearing may decline with aging 
[66], suggesting either a decrease in osteoblast activity or a desensitizing of osteocytes to mechanical stimuli. Therefore, alternative, more acceptable strategies with a lower risk of injury need to be explored.

WBV should be implemented in an environment where supervision could be provided. Vibration, with increased stresses on the bone, stimulates remodeling but may also decrease bone resorption. Studies show that it may increase femoral neck BMD in postmenopausal women and in lowerweight women, in addition to inhibiting bone loss after menopause. However, just a few studies have investigated the effect of WBV on BMD in older population and different protocols were employed in the studies. In addition, it is still unknown if these short-term effects of low-intensity WBV will persist or whether body will adapt (although the parameters can be constantly changed to account for adaptation). It is not known yet whether the benefits of WBV will disappear after the intervention is terminated, as it has been shown previously with other types of exercise [25]. The on-going "VIBES" trial investigated the effects of WBV on various bone and muscle parameters in postmenopausal women over a 2-year period [67], and results, when available, should provide more insight into the issue. This may shed further light on the mechanism by which WBV operates and may yield future areas of study. Overall, future studies are required to confirm these short-term findings and to investigate whether the long-term WBV and AEX still have positive effect on bone.

\section{Acknowledgment}

This paper was supported in part by CSREES/National Research Initiative/USDA, no. 2004-05287.

\section{References}

[1] NIH Consensus Development Conference, "Osteoporosis prevention, diagnosis, and therapy," NIH Consens Statement, vol. 17, no. 1, pp. 1-45, 2000.

[2] J. S. Finkelstein, S. E. Brockwell, V. Mehta et al., "Bone mineral density changes during the menopause transition in a multiethnic cohort of women," Journal of Clinical Endocrinology and Metabolism, vol. 93, no. 3, pp. 861-868, 2008.

[3] J. V. Lacey, P. J. Mink, J. H. Lubin et al., "Menopausal hormone replacement therapy and risk of ovarian cancer," Journal of the American Medical Association, vol. 288, no. 3, pp. 334-341, 2002.

[4] R. Marcus, B. Drinkwater, G. Dalsky et al., "Osteoporosis and exercise in women," Medicine and Science in Sports and Exercise, vol. 24, no. 6, pp. S301-S307, 1992.

[5] K. M. Chan, M. Anderson, and E. M. C. Lau, "Exercise interventions: defusing the world's osteoporosis time bomb," Bulletin of the World Health Organization, vol. 81, no. 11, pp. 827-830, 2003.

[6] B. Gutin and M. J. Kasper, "Can vigorous exercise play a role in osteoporosis prevention? A review," Osteoporosis International, vol. 2, no. 2, pp. 55-69, 1992.

[7] A. Heinonen, H. Sievänen, P. Kannus, P. Oja, M. Pasanen, and I. Vuori, "High-impact exercise and bones of growing girls: a 9-month controlled trial," Osteoporosis International, vol. 11, no. 12, pp. 1010-1017, 2000.

[8] M. Hatori, A. Hasegawa, H. Adachi et al., "The effects of walking at the anaerobic threshold level on vertebral bone loss in postmenopausal women," Calcified Tissue International, vol. 52, no. 6, pp. 411-414, 1993.

[9] D. J. Cavanaugh and C. E. Cann, "Brisk walking does not stop bone loss in postmenopausal women," Bone, vol. 9, no. 4, pp. 201-204, 1988.

[10] C. Rubin, G. Xu, and S. Judex, "The anabolic activity of bone tissue, suppressed by disuse, is normalized by brief exposure to extremely low-magnitude mechanical stimuli," FASEB Journal, vol. 15, no. 12, pp. 2225-2229, 2001.

[11] C. Rubin, A. S. Turner, R. Müller et al., "Quantity and quality of trabecular bone in the femur are enhanced by a strongly anabolic, noninvasive mechanical intervention," Journal of Bone and Mineral Research, vol. 17, no. 2, pp. 349-357, 2002.

[12] V. Gilsanz, T. A. L. Wren, M. Sanchez, F. Dorey, S. Judex, and C. Rubin, "Low-level, high-frequency mechanical signals enhance musculoskeletal development of young women with low BMD," Journal of Bone and Mineral Research, vol. 21, no. 9, pp. 1464-1474, 2006.

[13] C. T. Rubin, R. Recker, D. Cullen, J. Ryaby, J. McCabe, and K. McLeod, "Prevention of postmenopausal bone loss by a lowmagnitude, high-frequency mechanical stimuli: a clinical trial assessing compliance, efficacy, and safety," Journal of Bone and Mineral Research, vol. 19, no. 3, pp. 343-351, 2004.

[14] C. Delecluse, M. Roelants, and S. Verschueren, "Strength increase after whole-body vibration compared with resistance training," Medicine and Science in Sports and Exercise, vol. 35, no. 6, pp. 1033-1041, 2003.

[15] M. Roelants, C. Delecluse, M. Goris, and S. Verschueren, "Effects of 24 Weeks of Whole Body Vibration Training on Body Composition and Muscle Strength in Untrained Females," International Journal of Sports Medicine, vol. 25, no. 1, pp. 1-5, 2004.

[16] V. K. Goel, H. Park, and W. Kong, "Investigation of vibration characteristics of the ligamentous lumbar spine using the finite element approach," Journal of Biomechanical Engineering, vol. 116, no. 4, pp. 377-383, 1994.

[17] J. A. D. Anderson, E. O. Otun, and B. J. Sweetman, "Occupational hazards and low back pain," Reviews on Environmental Health, vol. 7, no. 1-2, pp. 121-160, 1987.

[18] R. Dandanell and K. Engstrom, "Vibration from riveting tools in the frequency range $6 \mathrm{~Hz}-10 \mathrm{MHz}$ and Raynaud's phenomenon," Scandinavian Journal of Work, Environment and Health, vol. 12, no. 4, pp. 338-342, 1986.

[19] N. Gusi, A. Raimundo, and A. Leal, "Low-frequency vibratory exercise reduces the risk of bone fracture more than walking: a randomized controlled trial," BMC Musculoskeletal Disorders, vol. 7, article 92, 2006.

[20] K. Brooke-Wavell, P. R. M. Jones, and A. E. Hardman, "Brisk walking reduces calcaneal bone loss in post-menopausal women," Clinical Science, vol. 92, no. 1, pp. 75-80, 1997.

[21] M. Y. Chien, Y. T. Wu, A. T. Hsu, R. S. Yang, and J. S. Lai, "Efficacy of a 24-week aerobic exercise program for osteopenic postmenopausal women," Calcified Tissue International, vol. 67, no. 6, pp. 443-448, 2000.

[22] S. Ebrahim, P. W. Thompson, V. Baskaran, and K. Evans, "Randomized placebo-controlled trial of brisk walking in the prevention of postmenopausal osteoporosis," Age and Ageing, vol. 26, no. 4, pp. 253-260, 1997.

[23] J. Ilich-Ernst, R. A. Brownbill, M. A. Ludemann, and R. Fu, "Critical factors for bone health in women across the age span: 
how important is muscle mass?" Medscape women"s health [electronic resource], vol. 7, no. 3, p. 2, 2002.

[24] J. Z. Ilich and R. A. Brownbill, "Habitual and low-impact activities are associated with better bone outcomes and lower body fat in older women," Calcified Tissue International, vol. 83 , no. 4, pp. 260-271, 2008.

[25] J. Iwamoto, T. Takeda, and S. Ichimura, "Beneficial effect of etidronate on bone loss after cessation of exercise in postmenopausal osteoporotic women," American Journal of Physical Medicine and Rehabilitation, vol. 81, no. 6, pp. 452457, 2002.

[26] S. Kirk, C. F. Sharp, N. Elbaum et al., "Effect of long-distance running on bone mass in women," Journal of Bone and Mineral Research, vol. 4, no. 4, pp. 515-522, 1989.

[27] E. A. Krall and B. Dawson-Hughes, "Walking is related to bone density and rates of bone loss," American Journal of Medicine, vol. 96, no. 1, pp. 20-26, 1994.

[28] S. R. Lord, J. A. Ward, P. Williams, and E. Zivanovic, "The effects of a community exercise program on fracture risk factors in older women," Osteoporosis International, vol. 6, no. 5, pp. 361-367, 1996.

[29] N. E. Lane, J. W. Oehlert, D. A. Bloch, and J. F. Fries, "The relationship of running to osteoarthritis of the knee and hip and bone mineral density of the lumbar spine: a 9 year longitudinal study," Journal of Rheumatology, vol. 25, no. 2, pp. 334-341, 1998.

[30] D. Martin and M. Notelovitz, "Effects of aerobic training on bone mineral density of postmenopausal women," Journal of Bone and Mineral Research, vol. 8, no. 8, pp. 931-936, 1993.

[31] B. A. Michel, N. E. Lane, A. Bjorkengren, D. A. Block, and J. F. Fries, "Impact of running on lumbar bone density: a 5-year longitudinal study," Journal of Rheumatology, vol. 19, no. 11, pp. 1759-1763, 1992.

[32] M. Y. C. Pang, J. J. Eng, A. S. Dawson, H. A. McKay, and J. E. Harris, "A community-based fitness and mobility exercise program for older adults with chronic stroke: a randomized, controlled trial," Journal of the American Geriatrics Society, vol. 53, no. 10, pp. 1667-1674, 2005.

[33] L. Welsh and O. M. Rutherford, "Hip bone mineral density is improved by high-impact aerobic exercise in postmenopausal women and men over 50 years," European Journal of Applied Physiology and Occupational Physiology, vol. 74, no. 6, pp. 511517, 1996.

[34] R. A. Wiswell, S. A. Hawkins, H. C. Dreyer, and S. V. Jaque, "Maintenance of BMD in older male runners is independent of changes in training volume or $\mathrm{VO}(2)$ peak," Journals of Gerontology A, vol. 57, no. 4, pp. M203-M208, 2002.

[35] S. M. P. Verschueren, M. Roelants, C. Delecluse, S. Swinnen, D. Vanderschueren, and S. Boonen, "Effect of 6-month whole body vibration training on hip density, muscle strength, and postural control in postmenopausal women: a randomized controlled pilot study," Journal of Bone and Mineral Research, vol. 19, no. 3, pp. 352-359, 2004.

[36] B. Ezenwa, E. Burns, and C. Wilson, "Multiple vibration intensities and frequencies for bone mineral density improvement," in Proceedings of the 30th Annual International Conference of the IEEE Engineering in Medicine and Biology Society (EMBS '08), pp. 4186-4189, August 2008.

[37] V. Brewer, B. M. Meyer, and M. S. Keele, "Role of exercise in prevention of involutional bone loss," Medicine and Science in Sports and Exercise, vol. 15, no. 6, pp. 445-449, 1983.

[38] G. A. Kelley, K. S. Kelley, and Z. V. Tran, "Resistance training and bone mineral density in women: a meta-analysis of controlled trials," American Journal of Physical Medicine and Rehabilitation, vol. 80, no. 1, pp. 65-77, 2001.

[39] T. Y. L. Liu-Ambrose, K. M. Khan, J. J. Eng, A. Heinonen, and H. A. McKay, "Both resistance and agility training increase cortical bone density in 75- to 85-year-old women with low bone mass: a 6-month randomized controlled trial," Journal of Clinical Densitometry, vol. 7, no. 4, pp. 390-398, 2004.

[40] G. Kelley, "Aerobic exercise and lumbar spine bone mineral density in postmenopausal women: a meta-analysis," Journal of the American Geriatrics Society, vol. 46, no. 2, pp. 143-152, 1998.

[41] G. A. Kelley and K. S. Kelley, "Exercise and bone mineral density at the femoral neck in postmenopausal women: a meta-analysis of controlled clinical trials with individual patient data," American Journal of Obstetrics and Gynecology, vol. 194, no. 3, pp. 760-767, 2006.

[42] H. M. Frost, "Bone 'mass' and the 'mechanostat': a proposal," Anatomical Record, vol. 219, no. 1, pp. 1-9, 1987.

[43] M. Martyn-St James and S. Carroll, "Meta-analysis of walking for preservation of bone mineral density in postmenopausal women," Bone, vol. 43, no. 3, pp. 521-531, 2008.

[44] K. M. Palombaro, "Effects of walking-only interventions on bone mineral density at various skeletal sites: a meta-analysis," Journal of Geriatric Physical Therapy, vol. 28, no. 3, pp. 102107, 2005.

[45] E. L. Smith, C. Gilligan, M. McAdam, C. P. Ensign, and P. E. Smith, "Deterring bone loss by exercise intervention in premenopausal and postmenopausal women," Calcified Tissue International, vol. 44, no. 5, pp. 312-321, 1989.

[46] A. Bérard, G. Bravo, and P. Gauthier, "Meta-analysis of the effectiveness of physical activity for the prevention of bone loss in postmenopausal women," Osteoporosis International, vol. 7, no. 4, pp. 331-337, 1997.

[47] H. M. Frost, "Perspectives: the role of changes in mechanical usage set points in the pathogenesis of osteoporosis," Journal of Bone and Mineral Research, vol. 7, no. 3, pp. 253-261, 1992.

[48] K. T. Borer, K. Fogleman, M. Gross, J. M. La New, and D. Dengel, "Walking intensity for postmenopausal bone mineral preservation and accrual," Bone, vol. 41, no. 4, pp. 713-721, 2007.

[49] J. Wolff, The Law of Bone Remodeling, Springer, Berlin, Germany, 1986, translated by Maquet, P and Furlong, R.

[50] C. Palumbo, S. Palazzini, and G. Marotti, "Morphological study of intercellular junctions during osteocyte differentiation," Bone, vol. 11, no. 6, pp. 401-406, 1990.

[51] C. Rubin, A. S. Turner, S. Bain, C. Mallinckrodt, and K. McLeod, "Low mechanical signals strengthen long bones," Nature, vol. 412, no. 6847, pp. 603-604, 2001.

[52] H. M. Frost, "Muscle, bone, and the Utah paradigm: a 1999 overview," Medicine and Science in Sports and Exercise, vol. 32, no. 5, pp. 911-917, 2000.

[53] S. Srinivasan, D. A. Weimer, S. C. Agans, S. D. Bain, and T. S. Gross, "Low-magnitude mechanical loading becomes osteogenic when rest is inserted between each load cycle," Journal of Bone and Mineral Research, vol. 17, no. 9, pp. 16131620, 2002.

[54] S. J. Sample, M. Behan, L. Smith et al., "Functional adaptation to loading of a single bone is neuronally regulated and involves multiple bones," Journal of Bone and Mineral Research, vol. 23, no. 9, pp. 1372-1381, 2008.

[55] S. von Stengel, W. Kemmler, S. Mayer, K. Engelke, A. Klarner, and W. A. Kalender, "Effect of whole body vibration exercise on osteoporotic risk factors," Deutsche Medizinische Wochenschrift, vol. 134, no. 30, pp. 1511-1516, 2009. 
[56] J. Flieger, TH. Karachalios, L. Khaldi, P. Raptou, and G. Lyritis, "Mechanical stimulation in the form of vibration prevents postmenopausal bone loss in ovariectomized rats," Calcified Tissue International, vol. 63, no. 6, pp. 510-514, 1998.

[57] J. Colantoni, D. Freeman, P. Arounleut, E. Kellum, W. K. J. Yu, and M. Hamrick, "Low magnitude vibration can inhibit muscle loss and increase mineralizing bone surfaces in aging mice," Journal of Bone and Mineral Research, vol. 23, p. S416, 2008.

[58] S. Torvinen, P. Kannus, H. Sievänen et al., "Effect of 8-month vertical whole body vibration on bone, muscle performance, and body balance: a randomized controlled study," Journal of Bone and Mineral Research, vol. 18, no. 5, pp. 876-884, 2003.

[59] L. Slatkovska, S. M. H. Alibhai, J. Beyene, and A. M. Cheung, "The efficacy of whole-body vibration in reducing bone in postmenopausal women: a meta-analysis," Journal of Bone and Mineral Research, vol. 23, p. S473, 2008.

[60] C. T. Rubin and L. E. Lanyon, "Regulation of bone mass by mechanical strain magnitude," Calcified Tissue International, vol. 37, no. 4, pp. 411-417, 1985.

[61] H. M. Frost, "Skeletal structural adaptations to mechanical usage (SATMU): 1. Redefining Wolff's law: the bone modeling problem," Anatomical Record, vol. 226, no. 4, pp. 403-413, 1990.

[62] YI. X. Qin, W. Lin, and C. Rubin, "The pathway of bone fluid flow as defined by in vivo intramedullary pressure and streaming potential measurements," Annals of Biomedical Engineering, vol. 30, no. 5, pp. 693-702, 2002.

[63] C. Rubin, A. S. Turner, C. Mallinckrodt, C. Jerome, K. Mcleod, and S. Bain, "Mechanical strain, induced noninvasively in the high-frequency domain, is anabolic to cancellous bone, but not cortical bone," Bone, vol. 30, no. 3, pp. 445-452, 2002.

[64] D. C. Gravelle, C. A. Laughton, N. T. Dhruv et al., "Noiseenhanced balance control in older adults," NeuroReport, vol. 13, no. 15, pp. 1853-1856, 2002.

[65] P. Cordo, J. T. Ingils, S. Verschueren et al., "Noise in human muscle spindles," Nature, vol. 383, no. 6603, pp. 769-770, 1996.

[66] C. H. Turner, Y. Takano, and I. Owan, "Aging changes mechanical loading thresholds for bone formation in rats," Journal of Bone and Mineral Research, vol. 10, no. 10, pp. 15441549, 1995.

[67] D. P. Kiel, M. T. Hannan, B. A. Barton et al., "Insights from the conduct of a device trial in older persons: low magnitude mechanical stimulation for musculoskeletal health," Clinical Trials, vol. 7, no. 4, pp. 354-367, 2010. 


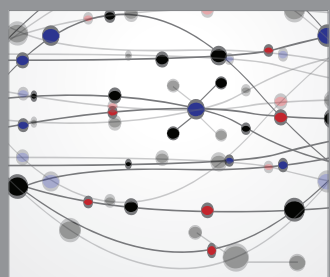

The Scientific World Journal
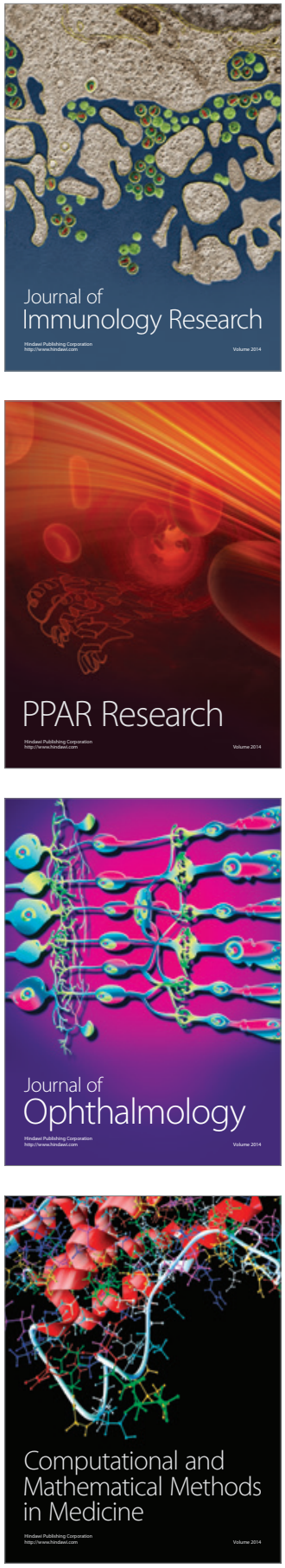

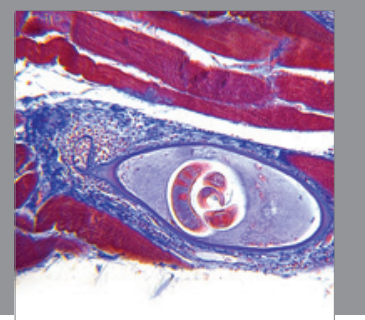

Gastroenterology

Research and Practice
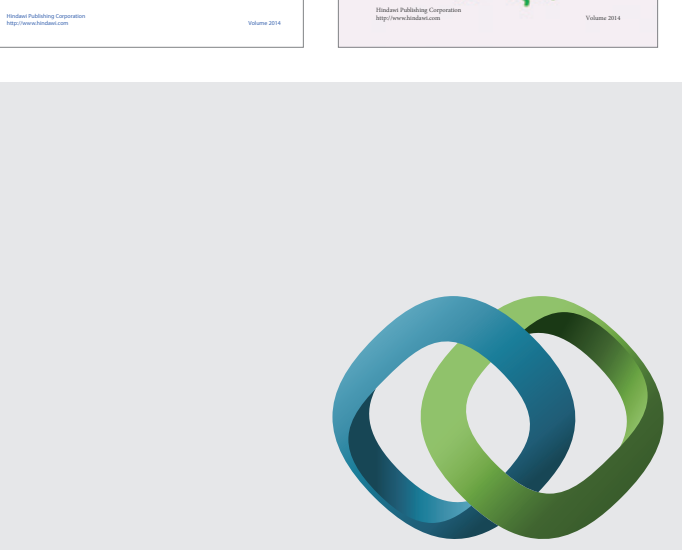

\section{Hindawi}

Submit your manuscripts at

http://www.hindawi.com
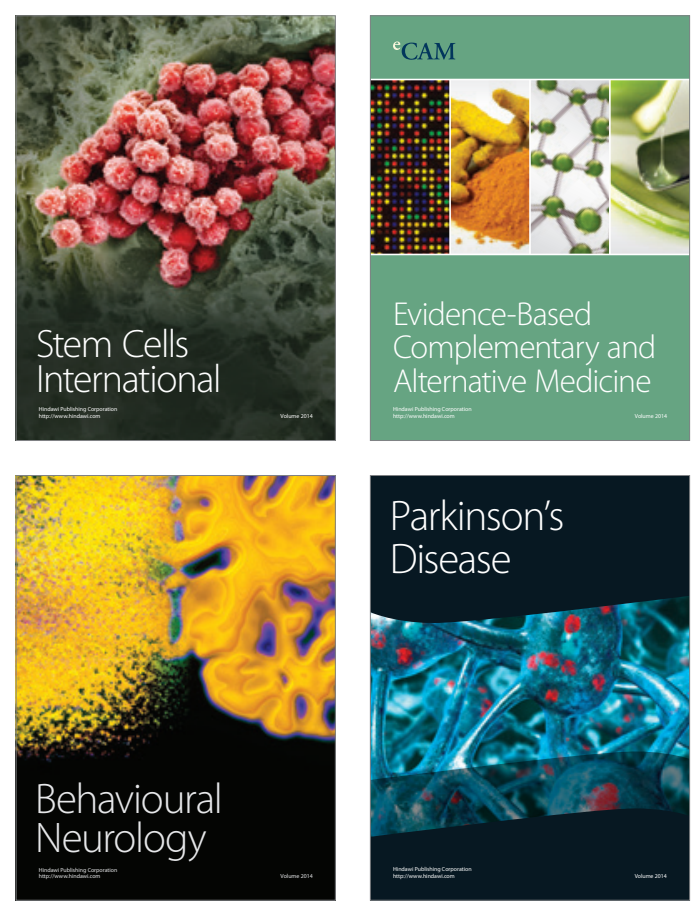

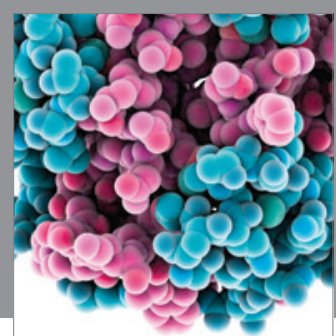

Journal of
Diabetes Research

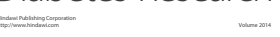

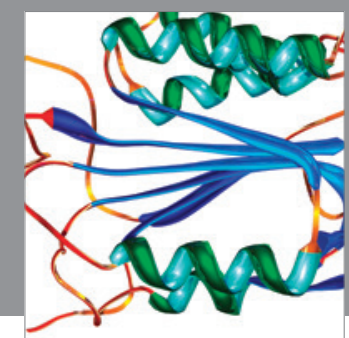

Disease Markers
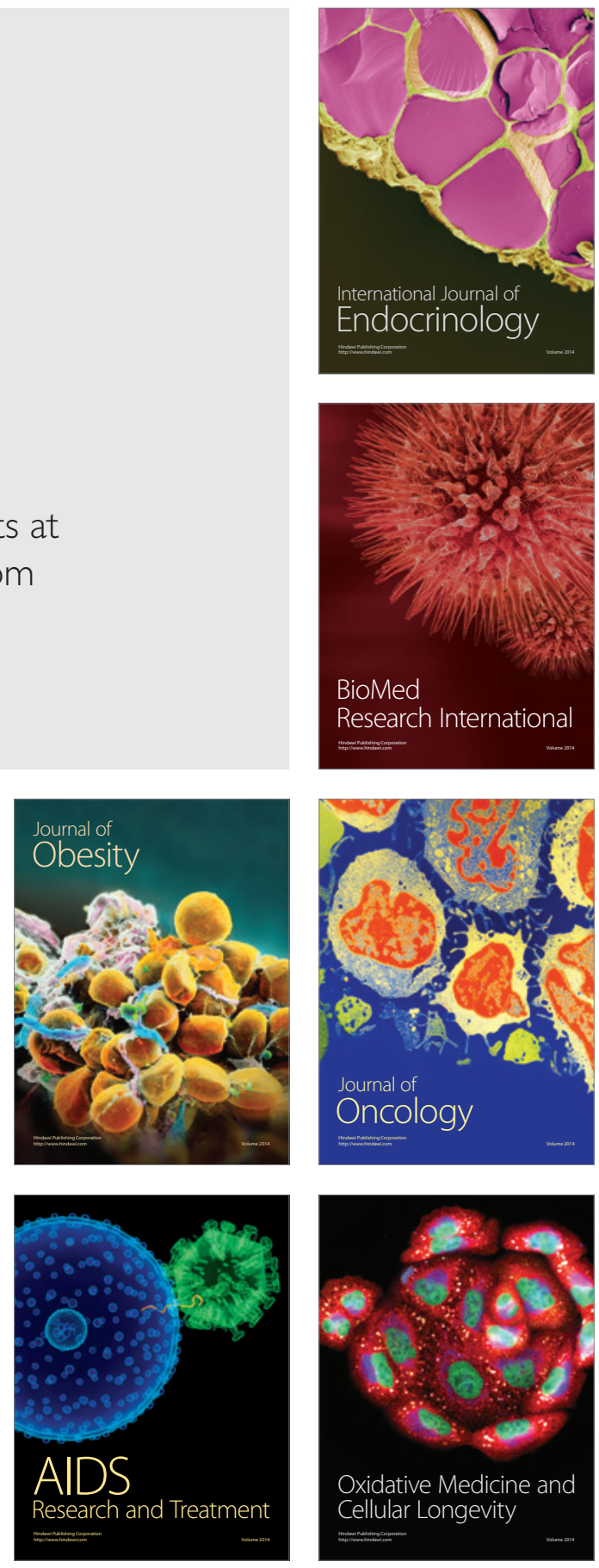